\title{
Application of different compost doses in Pinova and Golden Delicious apple orchards
}

\author{
Anita Szabó \\ University of Debrecen, Centre for Agricultural and Applied Economic Sciences, Faculty of Agricultural and Food Sciences and \\ Environmental Management, Institute of Agricultural Chemistry and Soil Science, Debrecen \\ szaboanita@agr.unideb.hu
}

SUMMARY

\begin{abstract}
Nowadays the success vegetable and fruit production are unimaginable without regular nutrient management. The animal husbandry is getting decrease, thereby there is the lack of organic fertilizer and it is suggested to find alternative nutrient supply methods. One of the ways to supply the required nutrients in an environmentally friendly way is the application of composts, which is less widespread so far, which is appropriate for the requirement of organic farming.

From the year of 2010 in each year, compost doses were applied in biological apple orchards in cooperation with the Institute of Horticultural Science. In the function of the years different changes were resulted by the compost treatments in the examined parameters in case of both apple species (Golden Delicious and Pinova). It was concluded that the dry matter, ash, total acids, sugar content and the vitamin $C$ changed versus time and species. It is supposed that the effect of compost treatments is getting visible.

According to the data higher dry matter, total acids and sugar content, (in some cases) ash were measured in case of the apple species Pinova, while the measurements showed higher vitamin C content in case of the species Golden Delicious.
\end{abstract}

Keywords: compost application, biological fruit production, quality indicators of apple

\section{ÖSSZEFOGLALÁS}

Napjainkban sikeres zöldség- és gyümölcstermesztés immár elképzelhetetlen rendszeres talajerö-visszapótlás nélkül. Mivel Hazánk állatállománya fokozatosan gyérül, ezért szervestrágya hiányában új, alternativ tápanyag utánpótlási formák után kell néznünk. A szükséges tápanyagok pótlásának egyik, eddig kevésbé elterjedt, környezetkímélö módja a komposztok alkalmazása, amely nagyszerüen megfelel a biotermesztést alkalmazók elvárásainak.

2010-töl kezdve minden évben a Kertészettudományi Intézettel együttmüködve, adott komposztdózisokat helyeztünk ki egy biotermesztés alatt álló almaültetvénybe. Ezen kezelések az évjárat függvényében mindkét almafajtánál (Golden Delicious és Pinova) eltérő változásokat eredményeztek a vizsgált paraméterekben. A szárazanyag-, a hamu-, az összes sav, a cukor-és a C-vitamintartalom változásában tendenciaszerü megállapitás egyelőre csak az évjárat hatásának és a fajtakülönbségeknek tudhatók be, de feltételezhetöen már a komposztkezelések hatása is kezdenek megmutatkozni.

Eredményeink azt mutatják, hogy a Pinova almafajta nagyobb szárazanyag-, összes sav-, cukor-és néhány esetben hamutartalommal, mig a Golden Delicious nagyobb C-vitamin tartalommal rendelkezik.

Kulcsszavak: komposzt kijuttatás, biogyümölcstermesztés, az alma minőségi jellemzői

\section{INTRODUCTION}

The apple production is the most important sector of fruit production in Hungary; it is $40 \%$ of the total fruit production. Although the production and also the consumption dropped during the previous period, intensive, high biological performance, stock-species combinational orchards were established resulting good quality production-performances in case of optimal and favorable site (Gonda and Apáti, 2011).

Nowadays it is an expected requirement from nutrient management to fulfil more conditions at the same time: to satisfy the rules of sustainability, to produce high quality goods effectively. It is suggested to emphases environmental friendly and gentle crop production technologies. The main characteristics of the integrated production are a gradation between the ecological and the traditional production method, because it reduces the use of the earlier permitted chemicals (El Titi et al., 1993; Mihályka et al., 2000; Papp, 2003; Holb, 2005).

The ecological cultivation is also known as organic production that is the technological method being the best in harmony with the environment. The requirements of this method do not tolerate the application of unnatural artificial materials. The principles of this are stricter than that of integrated technology because it is characterized by the total ban of foreign, artificial materials and certain procedures (Soltész, 1997). Furthermore the bio production is increasingly built for the natural cycles (Papp, 2003). This is the reason why the quantity and the quality of the production are much more insecure.

According to Gonda (2005) the mechanical cultivation, the use of powders containing minerals and the biological protection help in the defence against of the animal pests, pathogens and weeds in the organic farming system, while the crop residues, organic fertilizers, green manures as well as the composts produced by organic wastes and side products can improve the fertility of the soil and supply of nutrients uptaken by plants.

The nutrient supply (application of compost) affects the quality of fruits in a direct and indirect way. It has a direct effect on the nutritional contents of the fruits, while the indirect effect is reflected in the storage life and maturity of the crops (Nagy, 2009).

Our aim was to prove the favourable effect of a compost preparation under field conditions. Several compost preparations were tested is a pot experiment and the best was chosen for the field trial. A young organic 
apple orchard was selected as the place of the experiments in 2010. Within the orchard two apples species were treated with different compost doses the more sensitive and popular Golden Delicious (M9) and the more resistant, vital Pinova (M9). The aim of this study was to demonstrate the effect of compost doses on the nutrition indicators (dry matter, ash, total acidity, sugar and vitamin $\mathrm{C}$ content) of the fruit of certain apple species on acidic sandy soil from 2010 until today.

\section{MATERIALS AND METHODS}

The compost with patent composition was applied at first in the summer of 2010 in acidic sand soil of Pallag experimental Station of the University of Debrecen by Department of Horticultural Science Institute. The compost doses were rotated in an organically cultivated apple orchards planted in 2008. At the determination of the compost doses the nitrate directive was considered (81/2007. (IV. 25.) Hungarian Government Regulation), because in the first year the compost was applied twice. According to the above mentioned we could have applied compost doses with maximum $50 \mathrm{~kg} \mathrm{~m}^{-2} \mathrm{~N}$ content in the first year twice.

The applied amounts were calculated by the following way. The availably nitrogen amount of the compost (total $\mathrm{N}_{\mathrm{CaCl}_{2}}=726 \mathrm{mg} \mathrm{kg}^{-1}$ ) was measured and after that the applied amount of compost was calculated for each $\mathrm{m}^{2}$ (maximum dose: $6.90 \mathrm{~kg}$ ). Table 1. shows the $\mathrm{N}$ contents of soils of Pallag versus years and table 2 shows some characteristics of the experimental compost, while the applied compost doses that are in correspondence with $\mathrm{N}$ doses can be seen in the table 3 .

Table 1 .

The content of $0.01 \mathrm{M} \mathrm{dm}^{-3} \mathrm{CaCl}_{2}$-exratctable $\mathrm{N}$ forms of the soil in ecological apple orchards

\begin{tabular}{|c|c|c|c|c|}
\hline & \multicolumn{4}{|c|}{ 28.07.2010. } \\
\hline & Nitrate-N & Ammoniun & Organic-N & Total-N \\
\hline & \multicolumn{4}{|c|}{$\left(\mathrm{mg} \mathrm{kg}^{-1}\right)$} \\
\hline Bio $0-30 \mathrm{~cm}$ & 0.74 & 0.68 & 4.52 & 5.94 \\
\hline \multirow[t]{4}{*}{ Bio $30-60 \mathrm{~cm}$} & 0.41 & 0.00 & 4.27 & 4.68 \\
\hline & \multicolumn{4}{|c|}{ 09.03.2011. } \\
\hline & Nitrate-N & Ammoniun & Organic-N & Total-N \\
\hline & \multicolumn{4}{|c|}{$\left(\mathrm{mg} \mathrm{kg}^{-1}\right)$} \\
\hline Bio $0-30 \mathrm{~cm}$ & 2.08 & 1.15 & 3.54 & 6.78 \\
\hline Bio $30-60 \mathrm{~cm}$ & 1.36 & 1.71 & 2.71 & 5.78 \\
\hline
\end{tabular}

Table 2.

Some parameter of the experimental compost

\begin{tabular}{ccccc}
\hline \multicolumn{5}{c}{ Element contents of compost $\left(\mathrm{mg} \mathrm{kg}^{-1}\right)$ and $\mathrm{pH}$ value } \\
\hline N-total & $\mathrm{Mg}$ & $\mathrm{K}$ & $\mathrm{P}$ & $\mathrm{pH}$ \\
\hline 725.50 & 765.83 & 2368.57 & 137.83 & 6.94 \\
\hline
\end{tabular}

The compost doses mentioned before were applied in case of 7 trees per treatment $\left(1 \mathrm{~m}^{2}\right.$ of floor area of 1 tree). The spring compost doses were applied in April of 2011 and 2012. After the application it was rotated into the soil and irrigated with the walls built drip device. Fruit samples were taken from control and compost treated trees in case of both apple species (Golden Delicious and Pinova) in 3 replicates. The apple samples were collected in autumn each year before the harvest days. After the harvest the most important quality parameters of fruits were measured such as dry matter, ash, total acid, sugar and vitamin $\mathrm{C}$ content.

Table 3 .

Applied compost amount per treatments

\begin{tabular}{ccc}
\hline \multicolumn{2}{c}{ Applied N in the compost treatments } & Applied compost dosed \\
\hline$\left(\mathrm{kg} \mathrm{ha}^{-1}\right)$ & $\left(\mathrm{g} \mathrm{m}^{-2}\right)$ & $\left(\mathrm{kg} \mathrm{m}^{-2}\right)$ \\
\hline 0 & 0.0 & 0.00 \\
5 & 0.5 & 0.69 \\
10 & 1.0 & 1.38 \\
25 & 2.5 & 3.44 \\
50 & 5.0 & 6.88 \\
\hline
\end{tabular}

The dry weight was determined by the standard MSZ ISO 5520:1994. The ash content was analysed by the standard MSZ ISO 5520:1994, while the total acid contents was measured by the standard MSZ ISO 750:2001.

The sugar contents were measured by the following method: from each 3 apple some g was crushed to watch glass and the some drops from the juice of the samples were put in to the prism of UNIVERSAL MANUAL BRIX refractometer. The International Sugar Chemical Society (ISC) calculated a conversation table that make possible the calculation of the BRIX\% value determined by the refractometer to $\mathrm{g} \mathrm{dm}^{-3}$ sugar content (Kállay, 2006).

The vitamin $\mathrm{C}$ contents were measured with the following method: from each treatment 3 apples $20 \mathrm{~g}$ samples were crushed into a rubbing-mortar. The samples were rubbed with some $\mathrm{cm}^{3} 2 \%$ hydrochloric acid and then filter into $100 \mathrm{~cm}^{3}$ volumetric flasks with the help of filter paper and $40 \mathrm{~cm}^{3} \mathrm{HCl}$. After that the flasks were filled up until the sign with $2 \%$ hydrochloric acid. shake and the aliquot $\left(20 \mathrm{~cm}^{3}\right)$ was pipetted into $250 \mathrm{~cm}^{3}$ flasks. It was added $30 \mathrm{~cm}^{3}$ distilled water. $5 \mathrm{~cm}^{3}$ $2 \% \mathrm{HCl}$ solution. $5 \mathrm{~cm}^{3} 1 \% \mathrm{KJ}$ solution and $5 \mathrm{~cm}^{3}$ $0.2 \%$ starch indicator to this solution.

Statistical analyses: We used variance analyses for the processing of the data. All statistical analyses were performed with a Microsoft Excel Macro (Tolner et al., 2008; Vágó et al., 2008) according to Sváb (1981). With this program we determined the significance level of the treatment effect and significant differences at $\mathrm{P} \leq 0.05$.

\section{RESULTS AND DISCUSSION}

\section{The dry matter production of apple species between} 2010-2012

The dry mass production of apple species in the treated years is represented in figure 1. Samples were collected from 7-7 trees of the given treatment, and then the average values were calculated. As it is known, the weather of the certain year especially the amount of precipitation plays major role in the formation of fruits' especially apple species' nutrition content. This trend can be seen in case of the dry matter content for both apple species. In rainy 2010 we got less, while in 
drought 2011 we got more dry matter production. 2012 was an average year from the aspect of precipitation and the dry matter production was between the former values.

Figure 1: Dry matter content of apple in biological fruit cultivation $(\%)$

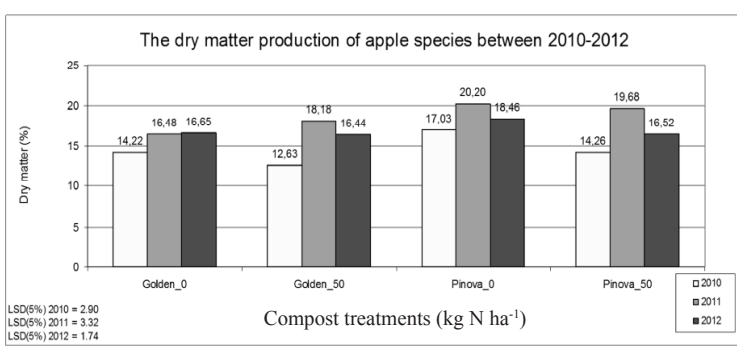

Due to variance analysis the species Pinova has significantly higher dry matter production in many cases than species Golden. The dry matter production of apples treated with compost was averagely less, but this reduction was not significant in any case.

The ash content of apple species between 2010-2012

The ash content of apple samples versus compost treatment is shown in figure 2. We observed similar trends to that of dry matter content. There is relationship between the amount of precipitation and the ash content of the samples. Thus we got the largest significant value in 2011.

Figure 2: Ash content of apple in biological fruit cultivation (\%)

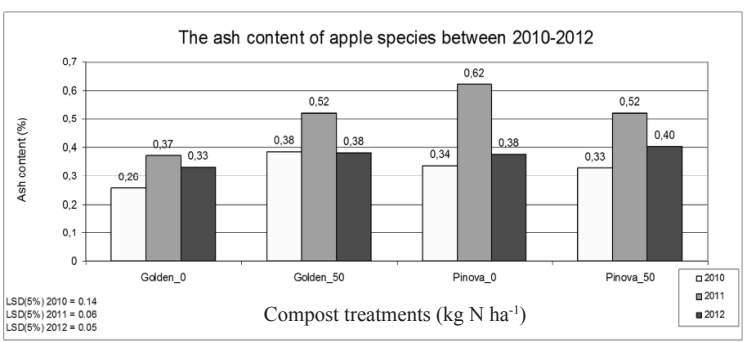

Comparing the apple species it can be stated that there is no significant difference between Pinova and Golden species from the aspect of ash content (except control treatment in 2011).

At control and compost treatments the ash content of Golden species increased significantly while for Pinova species the ash content decreased (or did not change) significantly.

The total acid content of apple species between 2010-2012

The total acid content of apple samples is illustrated in figure 3. The total acid content was inversely proportional with the amount of precipitation. It can be explained by the fact that too much precipitation dilutes the tissue moisture, while the lack of precipitation causing more concentrated solutions.
Pinova species has larger acid content then Golden. as can be markedly felt by tasting. Its acid content is much more balanced; it was not effected by precipitation. We got the same observation when we compared species treated by compost: the acid content of Golden increased as an effect of compost treatment (which can be explained by the ripening retentive effect of compost), while the acid content of Pinova did not change significantly.

Figure 3: Acid content of apple in biological fruit cultivation (\%)

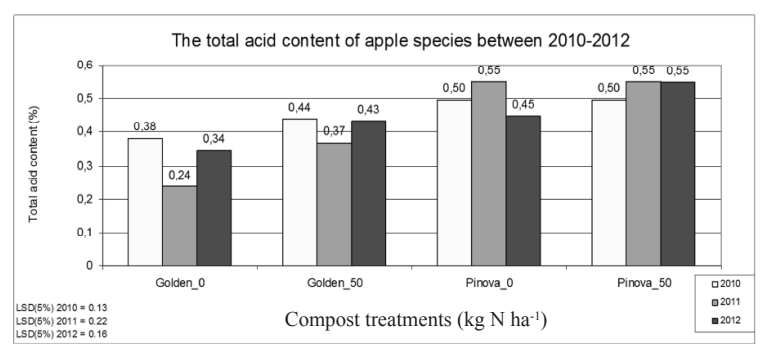

The sugar content of apple species between 2010-2012

The sugar content of apple samples during the experiment is shown in figure 4. The sugar content is in relationship with acid content. While there is no significant relationship between sugar content and precipitation, the trends of it are the same between the same treatments. The sugar content of apple species treated with compost fell back related to compost. It can be caused by the fact that trees pursued to shoot growing due to the better nutrient supply, there were greater yield, and sugar formation was secondary, but this statement is not confirmed with significant differences.

Figure 4: Sugar content of apple in biological fruit cultivation ( $\left.\mathrm{g} \mathrm{l}^{-1}\right)$

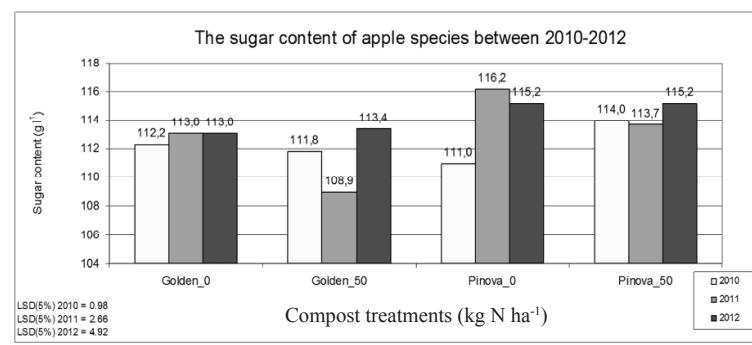

Comparing trees with the same treatment it can be concluded that the sugar content of Pinova was significantly greater that of Golden (except for 2012). It can cause by the fact that the time of sugar formation is different for the various species. At vintage the Pinova was more ripened than Golden, as during ripening starch transforms to sugar, and the acid content decreases in proportion with it.

The vitamin $C$ content of apple species between 2010-2012

The vitamin C content of apple species can be seen in figure 5. Probably there is also relationship between vitamin $\mathrm{C}$ content and precipitation. The less precipitation 
the greater the vitamin $\mathrm{C}$ content (except treated Pinova). Comparing the same treatments Golden apples have significantly greater vitamin $\mathrm{C}$ content, while there was no significant difference between compost and control treatments.

\section{Figure 5: Vitamin $\mathbf{C}$ content of apple in biological fruit} cultivation $(\mathbf{m g} \%)$

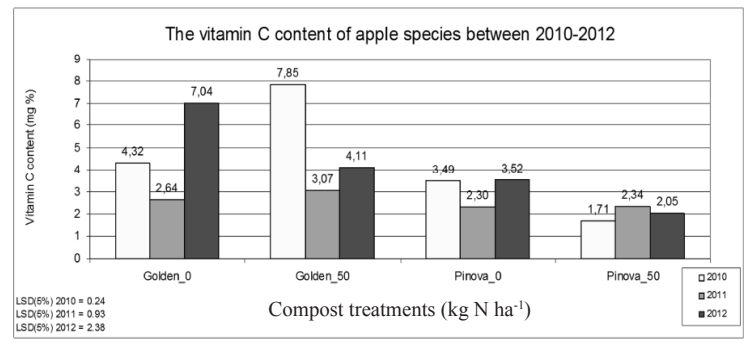

\section{CONCLUSIONS}

In summary, the compost treatments applied in the ecological apple orchards resulted differences in the examined parameters related to control. The changes of parameters depended on the weather of the certain year. In case of both apples species Golden Delicious and Pinova apple species.
Different tendencies were observed in the examined years, because 2010 was rainy, 2011 was drought and the present year was average, thereby significant spring rainfall improves the spring nutrient availability resulting strong shoot growth. The fruit development is suppressed by the vegetative part causing concentration in the nutrition indicators of the fruits.

During the 3 years the applied compost doses have been decomposing continuously, thus the effect of doses in not so apparent yet. To demonstrate the positive effect of compost it is suggested to increase the doses of compost per year.

The experimental results show that Pinova species has greater dry matter, total acid, sugar and in some cases ash content, while Golden Delicious has greater vitamin $\mathrm{C}$ contents.

\section{ACKNOWLEDGEMENTS}

I would like to say many thanks to prof. dr. István Gonda for providing the needed experimental place. the time spending for me and the professional advices. I am grateful to Gábor Lisku research station leader for the help during the experiments and the member working in the Research station in Pallag.

\section{REFERENCES}

El Titi, A.-Boller, E. F.-Gendrier, J. P. (1993): Integrated Production. Principles and Technical Guidelines. IOBC/WPRS. Bulletin 16.

Gonda I.-Apáti F. (2011): Almatermesztésünk helyzete és jövőbeni kilátásai. [In: Tamás J. (szerk.) Almaültetvények vízkészletgazdálkodása.] Debreceni Egyetem AGTC Kutatási és Fejlesztési Intézet - Kecskeméti Főiskola Kertészeti Főiskolai Kar. $14-17$.

Gonda I. (2005): A gyümölcsök ökológiai növényvédelmének elemei. [In: Holb I. (szerk.) A gyümölcsösök és a szőlő ökológiai növényvédelme.] Mezőgazda Kiadó. Budapest. 34-45.

Holb I. (2005): Az ökológiai (bio-) és az integrált termesztés és növényvédelem alapelvei és kapcsolatuk. [In: Holb I. (szerk.) A gyümölcsösök és a szölő ökológiai növényvédelme.] Mezőgazda Kiadó. Budapest. 11-13.

Kállay T. (2006): A forrás-fogyasztó elméletről. a K/Ca arány vonatkozásairól és a minőségi mutatók mérésének gyakorlatáról. Szóbeli közlés.

Mihályka Gy.-Mihályka Gy.-né (2000): Az integrált almatermesztés gyakorlata holland tapasztalatok alapján. Keszthelyi Akadémia Alapítvány. Keszthely. 9-12.
Nagy P. T. (2009): Gyümölcsösök tápanyag-gazdálkodásának időszerủ kérdései. DE AMTC Kutatási és Fejlesztési Intézet. Debrecen. 9-25., 190-191.

Papp J. (2003): Gyümölcstermesztés általános kérdései. [In: Papp J. (szerk.) Gyümölcstermesztési alapismeretek. Mezögazda Kiadó. Budapest. 23-26.

Soltész M. (1997): Az integrált gyümölcstermesztés alapjai. [In: Soltész M. (szerk.) Integrált gyümölcstermesztés.] Mezőgazda Kiadó. Budapest. 9-14., 365-371.

Sváb J. (1981): Biometriai módszerek a kutatásban. Mezőgazdasági Kiadó. Budapest.

Tolner, L.-Vágó, I.-Czinkota, I.-Rékási, M.-Kovács, Z. (2008): Field testing of a new. more efficient liming method. Cereal Res. Commun. 36: 543-546.

Vágó, I.-Tolner, L.-Eichler-Löbermann, B.-Czinkota, I.-Kovács, B. (2008): Long-term effects of liming on the dry matter production and chemical composition of perennial ryegrass (Lolium perenne L.). Cereal Res. Commun. 36: 103-106. 